\title{
Space-Temporary Analysis of External Geodynamic Disasters Occurred in Huaraz Province, Ancash - Peru
}

Ulises Francisco Giraldo Malca ( $\square$ ulises.giraldo@unmsm.edu.pe )

Universidad Privada del Norte Facultad de Ingeniería https://orcid.org/0000-0002-8559-018X

Haniel Josue Torres Joaquin

Universidad Privada Del Norte - Sede Lima Norte

Yeni Lucero Torres Tello

Universidad Privada del Norte Facultad de Ingenieria

Nicole Dalia Reyes Quispe

Universidad Privada del Norte Facultad de Ingenieria

\section{Research Article}

Keywords: Landslides, debris flows, ENSO, DEM, geographic information systems, mountain erosion

Posted Date: November 23rd, 2021

DOl: https://doi.org/10.21203/rs.3.rs-975710/v1

License: () (1) This work is licensed under a Creative Commons Attribution 4.0 International License. Read Full License 


\section{Abstract}

The natural disasters generated by external geodynamics are geological risks that constantly modify landscapes, with a more significant occurrence in mountainous areas, affecting populations and registering many victims in densely populated places. This research analyzes the events in Huaraz province, of Ancash department, in the central Andes of Peru, to find relationships between their occurrence and geographical factors such as altitude, slopes, climate, and extreme meteorological events. An inventory of events was made and classified as floods, mass gravitational movements, waterlogging or snow avalanches. Using QGIS software, spreadsheets and digital elevation models, information on natural disasters, altitude levels, physiography, river basins, meteorological data, and earthquakes were analyzed. As a result, it was obtained that the Quechua region registered $60 \%$ of all events; the Santa River basin $76 \%$; the wet season of the Peruvian Andes 78\%; and places with slopes between $8 \%$ and $50 \%$ (wavy relief) $72 \%$ of disasters. It is concluded that the best conditions for these events are the intense rainfall and the undulating reliefs, predominant in the Quechua region. Likewise, floods are the disasters that register the most significant number and generate the most damage in Huaraz province. Finally, it was determined that high-intensity El Niño-Southern Oscillation processes do not necessarily increase the number of events for the study area.

\section{Introduction}

External geodynamic processes, also called exogenous, are represented by processes occurring at the earth's surface, which influence the evolution and modelling of the landscape (Liu et al., 2020; Mas-pla \& Bach, 2008; J. Medina, 1991), destroying rock formations raised by internal geodynamics and dragging debris to lower places (Fan et al., 2018; Tarbuck \& Lutgens, 2005). These types of events frequently occur in mountainous areas, caused mainly by intense rainfall, cycles of freezing and thawing of glaciers (Oliver-Smith, 2014; Vit Vilímek et al., 2013), by earthquakes (Balzano et al., 2019; Iverson, 2000; Laimer, 2017; Serey et al., 2019), climate change, the occurrence of the El Niño - Southern Oscillation (ENSO) event and glacial activity (Menacho Agama, 2018; Valderrama Murillo et al., 2016; Vít Vilímek et al., 2014). Depending on the atmospheric agent that originates it and the factors that intervene in its development, they can be classified into mass gravitational movements, water flows (flood), snow avalanches, wind, littoral, coastal and glacial erosion (Lario \& Bardají, 2017; J. Medina, 1991).

The ENSO is a complex cyclical event that affects atmospheric and oceanic processes in the tropical Pacific region, occurring every 2 to 7 years, whose relations are insufficiently understood (Vit Vilímek et al., 2013). It presents a considerable irregularity in amplitude, duration, evolution and spatial structure (Chen et al., 2019); their effects extend throughout the globe for more than a year (Strahler, 1989). Its occurrence leads to a series of disturbances in the dry climates of the western slope of the Andes. In average years, the center of convection and precipitation is usually over the western Pacific, but during ENSO, the location moves to the eastern Pacific (Chen et al., 2019). This event causes the formation of convective clouds and heavy rainfall over the desert coast (Oliver-Smith, 2014) and the Peruvian maritime yunga, without vegetation and soils with little protection against water erosion, producing extreme events such as floods and mass gravitational movements. In Peru it is known as the occasional absence of the cold Humboldt sea current, a product of the weakening of the South Pacific anticyclone that interrupts the outcrop of deep waters and increases the temperature of surface waters.

Various mass movements occur due to earthquakes, and they can be verified in different places around the world. An example is the case of Quetta and its surroundings (Pakistan), that during the $7.7^{\circ}$ earthquake on the Richter scale, which occurred on May 31 st, 1935 , it triggered various external geodynamic events, causing the death of more than 30,000 people; and likewise, what happened after the Kashmir earthquake in October 2005 triggered 1,293 mass movements in 174 locations in Balakot, Pakistan with at least 100,000 dead and significant material losses (Khattak et al., 2010; Rahman et al., 2014). Large earthquakes such as Chi-Chi and Wenchuan generated a variety of mass landslides with a deposit of materials in the called "glacial lake outburst flood GLOF" (Emmer, 2017; Huang \& Li, 2014; Lin et al., 2007); ten of thousands of landslides were triggered by the Gorkha and Dolakha earthquakes in Nepal (Kargel et al., 2016; Martha et al., 2017).

In regions such as the Himalayas, mass movements are mainly caused by earthquakes and heavy rainfall, the combination of which accelerates the frequency of such events (Rahman et al., 2014). They even increase the risk of overflowing glacial lakes and the natural formation of temporary dams due to the obstruction of watercourses, which, when collapsing, cause destructive flows (Rahman et al., 2011).

Keefer (1984) proposes a typical maximum distance from the epicentre of the earthquake for the occurrence of mass movements. It can vary according to the earthquake's magnitude, presenting an area of $0 \mathrm{~km}^{2}$ for a $4^{\circ}$ earthquake and approximately $500,000 \mathrm{~km}^{2}$ when the earthquake is $9.2^{\circ}$ on the Richter scale. For example, in Peru on May 31st, 1970, there was an earthquake of magnitude $7.9{ }^{\circ}$; its epicentre was 44 km southwest of Chimbote. However, the most significant damage occurred in the Santa River valley, causing the death of 10,000 people in Huaraz city and an avalanche due to the breaking of a block of glacier ice that buried Yungay city (Emmer, 2017) and caused the death of 22,000 people (Castaños \& Lomnitz, 2012).

The Peruvian Andes are vulnerable to erosive processes due to: their high relief, steep slopes, shallow soil depth, geological instability and climate variability, which intensified and amplified the effects they generate in their environment, having significant implications on the health of ecosystems and people's wellbeing (Frey et al., 2018; Guevara, 2017; Mergili et al., 2015; Oliver-Smith, 2014; Tacconi Stefanelli et al., 2018). Precisely, Ancash department, with highly rugged physiography, has been affected by natural disasters due to orogenic activity, climate change and growing demographic pressure (Vit Vilímek et al., 2013).

According to Bonnot (1984), Huaraz province presents different geological structures, which are predisposed to mass movements, generated mainly by the different climates that characterize each of the five levels of altitude of the study area, geographically distributed on the slope western Cordillera Blanca and both slopes of the Cordillera Negra. Other triggering causes include human intervention (Hegglin \& Huggel, 2008), such as modifications in stress conditions due to discharges or overloads, alterations in surface drainage, changes in infiltration processes, decrease in vegetation cover (Casamitjana \& Carl, 2019), or the rapid urbanization process (Castaños \& Lomnitz, 2012; Chacón et al., 2005; Meléndez de la Cruz, 2018; Suarez, 1998). 
In Peru, it is necessary to identify the most relevant factors in mass movement processes in the Andes, which allows improving risk management and reducing the impact on people. For that, this work aims to determine the relationships between the external geodynamic events that have occurred in Huaraz province and the geomorphological complexity of its territory characterized by the different levels of altitude, its physiography, and the types of vegetation cover that protect its surface.

\subsection{Study Area}

The Huaraz province is part of the Áncash department, located between latitudes 9 ${ }^{\circ} 20^{\prime} 48$ "S - 9 ${ }^{\circ} 48^{\prime} 3^{\prime \prime} \mathrm{S}$; and longitudes $77^{\circ} 15^{\prime} 56^{\prime \prime} \mathrm{W}-78^{\circ} 2^{\prime} 31^{\prime \prime} \mathrm{W}($ Figure 1), whose territory of $250,697.88$ ha is on the Cordillera Negra to the west and the Cordillera Blanca to the east.

It presents a rugged relief, where many geomorphological processes reduce energy imbalances due to differences in elevation existing over small distances (Mergili et al., 2015). It has an altitudinal variation from $525 \mathrm{~m}$ a.s.l., at the confluence of the Remate and Sensen Grande streams in the Pampas Grande district, to $6.131 \mathrm{~m}$ a.s.l., on the summit of the Rurichinchay mountain, Independencia district. Therefore, Huaraz province is distributed in 5 of the 8 altitude levels or "regions" proposed by Pulgar Vidal (2014), that was described below:

\section{Maritime Yunga Region}

It is constituted by the sector of the western slope of the Andes Mountains that extends between 500 and 2,300 m a.s.I. (Pulgar Vidal, 2014). It has the ecoregions of subtropical Coastal Desert above $525 \mathrm{~m}$ a.s.I., and Desert Scrub-Dry Forest above 1,000 m a.s.l. (Britto, 2017). It is characterized by being prone to debris flows during summer rainfall.

In this region, the Pariacoto conventional meteorological station (CMS) is at 1,312 $\mathrm{m}$ a.s.l., with an average annual temperature of $19.4^{\circ} \mathrm{C}$ and an average annual rainfall of $115 \mathrm{~mm}$. According to Thornthwaite's classification, it has an arid climate, with zero excess water, corresponding to the second megathermal, and a low thermal efficiency concentration in summer (E d B2' a'). Likewise, the CMS Chacchan, located in the Pariacoto district at an elevation of 2,266 m a.s.I. (near to the border with the Quechua region) shows average annual precipitation values of $225.4 \mathrm{~mm}$, which according to the Köppen classification, would be Desert (BW) with scant rainfall concentrated in December to March.

According to the national vegetation cover map, this area is the cardonal (cacti) with 13,111 ha, riparian forests with 199 ha and shrubby scrub with 23,725 ha.

\section{Quechua Region}

refers to temperate lands, optimal for human life, rich in agricultural soil (Pulgar Vidal, 2014), included in the Andean zone between 2,300 m a.s.l. and 3,500 m a.s.l. characterized by an undulating relief, being able to present steep sections, and where the inter-Andean valleys of greater fertility are found, such as the Santa River (Britto, 2017), the most densely populated sector of the Andes. This territory has the ecoregions of Mesoandine, Montane Rain Forest, Northwest Montane Rain Forest, Seasonal Dry Forest and Desert Scrub - Dry Forest (Britto, 2017).

There is the Cajamarquilla CMS in La Libertad district at 3,286 m a.s.l., located in the Casma river basin whose data, after being processed, shows an average annual temperature of $12.8^{\circ} \mathrm{C}$ and an average annual rainfall of $495 \mathrm{~mm}$. Thornthwaite's classification presents a dry to sub-humid climate, with moderate excess of water in summer, corresponding to the first microthermal, and a low concentration of thermal efficiency in summer (C1 s B1' a'). As there was no data from a station located in Huaraz province within the Santa River Basin, it was decided to work with the Recuay automatic meteorological station (AMS), which is located close to the study area, at the height of 3,431 $\mathrm{m}$ a.s.l., that shows an average annual temperature of $15.1^{\circ} \mathrm{C}$ and an average annual rainfall of $831 \mathrm{~mm}$. It is a sub-humid to a humid climate, with a slight water deficit in any season, corresponding to the second mega-thermal, and a low concentration of thermal efficiency in summer (C2 r B2' a'). Likewise, the Anta CMS located at an elevation of 2,760 m a.s.l., shows average annual precipitation values of $643 \mathrm{~mm}$, which according to the Köppen classification, corresponds to a Temperate climate with dry winter (Cw). According to the national vegetation cover map, in this sector, there are 30,543 ha of predominantly shrubby scrub on the western slope of the Cordillera Negra, 33 ha of Meso-Andean relict forest, 54 ha of high Andean grassland, 135 ha of forest plantation and 22,673 ha of predominant agricultural plantations in the Santa River basin.

\section{Suni or Jalca Region}

refers to the cold highlands, with undulating relief, sometimes steep and rainier than the previous ones (Pulgar Vidal, 2014); it includes the terrain located between $3,500 \mathrm{~m}$ a.s.l., and the 4,000 $\mathrm{m}$ a.s.I. It is place to the jalca, desert puna and wet-dry puna ecoregions (Britto, 2017). According to the Peruvian vegetation cover map, this area has 7 ha with little and no vegetation, 308 ha of bofedal (high Andean wetlands), 153 ha of high Andean relict forest, 13,587 ha of shrubby scrub, 16,456 ha of Andean grassland, 104 ha of forest plantations and 15,083 ha of agricultural plantations. In areas with arid and cold climates, there is a greater vulnerability to mass movements due to low levels of chemical weathering, low soil and scarce vegetation, presenting rocks exposed by a rapid tectonic uplift (Mergili et al., 2015).

The Pira CMS, located in Pira district in the Casma river basin, at an elevation of 3,720 $\mathrm{m}$ a.s.l., shows average annual precipitation values of $686 \mathrm{~mm}$, which according to the Köppen classification, would have a Temperate climate with dry winter (Cw) or cold and dry winter Borealis with periodic rain in summer (Dw).

Puna Region: denomination given to the cold and extensive high Andean plateaus, of tame hills, rugged yellowish grasslands, deserted and wild, rich in pastures, habitat of wild South American camelids (Pulgar Vidal, 2014), it comprises the territory between 4,000 m a.s.l., and the 4,800 m a.s.I. According to Pulgar Vidal (2014), in places where the mountain range does not exceed 5,000 m a.s.l. constitutes the top of the summits, with a soft to abrupt topography by sharp slopes and springs of streams, housing the ecoregions of desert puna and wet-dry puna (Britto, 2017), there is the storage of water contained in 
wetlands and for a significant presence of lagoons. It presents the following plant covers: 14,253 ha with scarce and no vegetation, 861 ha of wetlands, 1,519 ha of high Andean relict forest, 238 ha of shrubby scrub, 71,289 ha of Andean grassland and 13 ha of forest plantation.

As we did not have data from a station in Huaraz province on this altitude level, we decided to use the Milpo CMS, located in the Catac district, Recuay province. It is close to the study area, at an elevation of 4,400 m a.s.l., which shows average annual precipitation of 1,141.3 mm, which according to Koppen's classification, it would be Boreal in cold and dry winter with periodic rain in summer (Dw).

Janca or Cordillera Region: It includes the snow-capped peaks of the Andes, which present a frigid climate with normally solid rainfall (Pulgar Vidal, 2014). It is made up of the entire surface located above $4,800 \mathrm{~m}$ a.s.l., where the highest peaks of the Andes are found. Starting at $5,200 \mathrm{~m}$ a.s.I. it is covered by glaciers or rocky outcrops devoid of soil and vegetation, denoted by an extremely rugged physiography (Britto, 2017), predominantly glacial and physical erosion that causes avalanches and rock slides (Ingemmet, 1989). In the past, its glaciers formed the moraines that dammed the reservoirs that currently constitute the water reserves, maintaining the provision of streams (by runoff) and aquifers (by infiltration) in the basin. On the other hand, according to the Map of Vegetal Coverage of Peru (2015) in this level of altitude, the following units are presented: high Andean areas with little or no vegetation (8,747 ha), Andean grassland (51 ha) and area covered by glaciers (11,935 ha).

The Huaraz province is part of the Santa River basin that includes the western slope of the Cordillera Blanca and the eastern slope of the Cordillera Negra, as well as the basins of the Casma River, Culebras River, and the Inter-basin 1375959 (denomination established by the National Water Authority) locally called Río Seco, located on the western slope of the Cordillera Negra.

Huaraz is the second most populated province in the department, housing 163,936 inhabitants that represent 15.1\% of the population of Ancash (INEI, 2018), who live in 1,264 populated centers. These populated centers are distributed in the 4 hydrographic basins as follows: 593 towns (47\%) are in the Santa River basin; the Casma river basin contains 505 populations (40\%); the Culebras river basin has 164 localities (13\%), and the Rio Seco Inter-basin has only 2 populated centers $(0.2 \%)$.

Most of its urban areas show a high risk of natural disasters of glacial origin (Ribeiro de Figueiredo, 2017). The best example is Huaraz city, which concentrates most of the province's urban population (Gobierno Regional de Áncash, 2014). It is a risk because the Quillcay River crosses it. According to Valderrama et al. (2013), it is located on an alluvial fan, where frequently happen floods, such as the 1941 catastrophe (Véliz, 1974), produced by snow avalanches or landslides that occur at the headwaters of the glacial valleys of the rivers that descend from the Cordillera Blanca such as Cojup, Llaca, Quilcayhuanca and Shallap (Indeci, 2003a).

Ferro (2009) indicates that after the 1941 disaster, Huaraz city reoriented its expansion towards the south with rapid urbanization and the appearance of human settlements such as Villón Bajo, Bellavista, Nueva Florida, Shancayan, Patay, Los Olivos, Vista Alegre, Rosas Pampa and Tacllan. According to Indeci (2003b), they present a high vulnerability due to their exposure to intense geological phenomena and limited resilience. Precisely one of the most vulnerable areas is the Río Seco sector, located to the south of the city, where the danger is the probable occurrence of flood due to extraordinary rains since its dejection cone has been occupied by some of the aforementioned human settlements (Silva Lindo et al., 2017).

According to Valderrama et al. (2013), the lithology of the province shows that it is mainly made up of volcanic, intrusive and sedimentary rocks, where the soil and expansion areas of the city of Huaraz are mainly made up of intrusive rocks -granites and granodiorites- (Bonnot, 1984), predominant in the Cordillera Blanca batholith. On the other hand, the Cordillera Negra is composed mainly of volcanic rocks -riolites and andesites- (Bonnot, 1984); it presents a less resistant soil and is susceptible to erosion.

Likewise, the Huaraz province presents modern and ancient faults. One of them is the active fault of the Cordillera Blanca, which is formed by a system of normal-type faults, which may be related to earthquakes of great magnitude (Indeci, 2003b).

According to the DesInventar database, a total of 46 seismic movements were registered in the period 1970-2012, in Ancash department, the years with the highest occurrences were: 1970 with 14 records; 1985 with 6 earthquakes; and 1972, 1977, 1987, 1996 with 3 events each. The earthquakes with the highest magnitude were: May 31, $1970\left(M=7.9^{\circ}\right)$, December 9, $1970\left(M=7.5^{\circ}\right)$, January $25,1988\left(M=5.2^{\circ}\right.$, in Huaraz district $)$ and 18 April $1996\left(M=5.6^{\circ}\right.$, Independencia district).

\section{Methods}

\subsection{Search and analysis of bibliographic information}

This research is quantitative, exploratory, and correlational, and it was developed through computational and statistical techniques. The technique used was a documentary review using a matrix as a data collection instrument. Information was searched in different databases, which allowed access to virtual books, disaster records and especially recognized journals that provided relevant, trustworthy, and quality articles. In the same way, studies were obtained from competent institutions in risk assessment, such as the Geological, Mining and Metallurgical Institute (Ingemmet) and the National Civil Defense Institute (Indeci). The final record constitutes an inventory of the 100 natural disasters of external geodynamic that occurred in the study area.

\subsection{Typification of external geodynamic events}

The spontaneous movements of soil, regolith and rocks that are produced by the action of gravity, known collectively as mass movements (Strahler, 1989), can be associated with the dynamics of runoff water, ice and snow that contribute to their denudation and modelling of the relief (Guevara, 2017). 
The factors that cause them are varied and are divided into two large groups according to the Geological Mining Metallurgical Institute (Dávila, 1994): Static (faulting or stratification) and Dynamic (Climatological, hydrological, seismic, and anthropogenic).

The different types of meteorological phenomena constitute the causes of different external geodynamic processes, as observed in moments with an abundant rainfall regime of a long time, which causes the saturation of deep levels of the ground because of phreatic variations, facilitating those areas of significant instability with deep breaking surfaces to be altered or reactivated, and manifesting in the form of creeping, sliding or rotational sliding. In contrast, having periods of heavy rain for a short time only produces superficial instabilities (Mergili et al., 2015).

The different processes that can have in Huaraz province (due to their geographical characteristics) were classified into four large groups depending on the predominant transport agent and the material type that is displaced, based on the studies of Vit Vilímek et al. (2013) and Varnes, (1978), which are mentioned below:

2.2.1. Gravitational movements in mass: Set of processes of soil and rock mass transport downhill by the influence of gravity (Cruden, 1991), mainly in places with steep slopes. According to Vit Vilímek et al. (2013), they are caused by prolonged rains that saturate the soil or subsoil on an impermeable layer, causing the movement of the upper strata to lower levels. This concept is used as a synonym for landslides (Mergili et al., 2015), in which portions of loose material (sediments and regolith) move, separating from their original formation (Sandoval, 2019). The undermining of slopes can cause them from fluvial and anthropic activity, water infiltration (Zavala et al., 2010), seismic movements, activation of geological faults (Sandoval, 2019), or the same weathering (Concha et al., 2017). Soil creeping also called creeping, is based on the slow descent of the surface layers of soil by the slopes (Guevara, 2017) of moderate slopes, whose occurrence is not violent (J. Medina, 1991). According to Strahler (1989), debris cones are caused by physical weathering processes that cause rock fragments to detach and fall on steep walls and high mountains, accumulating at the slope base. The slow downward movement of these rock fragments gives rise to the formation of rocky glaciers in the form of folds that curve according to the direction of movement.

2.2.2. Floods: Sandoval (2019) indicates that they are usually made up of a mixture of detrital material saturated with water and/or rock fragments of different sizes, which in Peru are called huaycos (Valdez, 2015). They usually happen in arid and semi-arid regions, where the rainy season generates intense erosion processes (Sandoval, 2019; Suarez, 1998), such as those that occurred during ENSO events (Valderrama Murillo et al., 2016). Vit Vilímek et al. (2013) typify it as a local term for debris flow, caused by the abundance of unconsolidated (unstable) loose material on the surface of the slopes, steep slopes and the scarce or null vegetation cover (Sandoval, 2019). Also, it can be produced by the falling blocks of ice or rocks that produce the breaking of moraine dikes or the overflow of lagoons, dragging debris through the streams (Hungr et al., 2014; Véliz, 1974). In this classification, there are mudflows, which according to Strahler (1989), are a "stream of fluid mud that slides through the canyons of mountainous regions" carrying with it fragments of rock that causes areolar erosion in its path (Guevara, 2017). The most fluid type of mud run with a weak consistency is called a debris flood (Strahler, 1989).

2.2.3. Snow avalanche: Partial or complete movement of a snow layer, going from a solid to a fluid state (Sanz-Ramos et al., 2020), which constitutes a natural hazard of great importance in numerous mountainous regions around the world (Casteller et al., 2009). This type of event can be triggered by changes in the internal structure of the snow, external factors (temperature, wind, humidity gradients, deposition of new snow), human activity (detonations, traffic on snow) and factors inherent such as topography (Schweizer et al., 2003). They are characterized by the sliding of one or more cohesive blocks supported on a weak layer of snow located on moderate slopes $\left(28-45^{\circ}\right)$, with an initial density of around $300 \mathrm{~kg} / \mathrm{m}^{3}$ and a displacement speed that can be over $20 \mathrm{~m} / \mathrm{s}$ (Sanz-Ramos et al., 2020).

2.2.4. Waterlogging: According to the RAE it implies temporary flooding of lands not usually covered with water. This situation happens in the lower parts, adjacent to the banks of rivers, lakes, lagoons, or dams, because of the overflows that occur when their carrying capacity is exceeded. It usually happens in the wet season and has a seasonal character (Silva, 2018), mainly when heavy rainfall occurs in short periods (Concha et al., 2017), such as those that occurred during an ENSO (Tinoco Meyhuay, 2019). Likewise, they can be generated by the fall of avalanches, glacial masses or large rocks to the periglacial lagoons (Alvarez, 2020), the breaking dams, the activation of dry streams (L. Medina \& Gonzales, 2018), the expansion of lagoons or elevation of the phreatic level. Also, it is being caused by anthropogenic actions such as alteration of channels, the intervention of basins, extraction of granular material, deforestation and overgrazing (Silva, 2018). According to Vergara et al. (2011), the surfaces with greater susceptibility to waterlogging have slopes of less than $2^{\circ}$ ( $3.49 \%$ ) corresponding to fluvial plains such as meanders and alluvial terraces, and those surfaces with slopes between $2^{\circ}$ and $5^{\circ}(3.49 \%-8.75 \%)$ have a moderate susceptibility in foothills with river valleys and hills.

\subsection{Geolocation and geoprocessing of events in Huaraz province}

In the case of the DesInventar database was observed that most of the systematized records did not have location coordinates or showed an unreliable location. For this reason, it was decided to georeferenced them based on their description. The georeferencing was carried out with the coordinates indicated by the source or through the data provided by its description, using the quadrants of the national topographic map 1 / 100,000 of the National Geographic Institute - IGN: 19-i (Huari), 19-h (Carhuaz), 20-g (Culebras), 20-h (Huaraz), 20-i (Recuay); the inventory of populated centers (ESCALE web platform -

Downloading spatial information from the Education Ministry); Google Earth software, among others. When they were located referentially, they were assigned a digitized point in the open-source QGIS software, obtaining the UTM coordinates for each record in WGS 84 datum.

According to Doyle (1978), a Digital Elevation Model -DEM- is understood as a set of numerical data that describes the spatial distribution of a characteristic of the territory, such as the elevation in meters above sea level in raster format, where each pixel has altitude data as assigned value (Contreras \& Odriozola, 2016). For this study, 2 ASTER GDEM quadrants were downloaded from the Huaraz province (S10W79; S12W78). They joined a single DEM in the QGIS software with the miscellaneous raster tool "Combine ...". The slope map was generated using the raster analysis tool "Slope ...", and the ranges classified its result typified in the Land Classification Regulation by its Greater Use Capacity (Supreme Decree 017-2009-AG) with the tool of raster analysis "Reclassify". Finally, it was vectorized with the raster conversion tool "Polygonize (raster to vector) ...". Likewise, the map of levels of altitude was prepared from the DEM of the province, reclassifying its values to the ranges established by Dr. Javier Pulgar Vidal (1941). In addition, the information of the existing plant covers in the study area was obtained from the Plant Cover Map of Peru 2015 (downloaded from the Geoserver of the Ministry of Environment).

Page 5/13 
Finally, the information was extracted from the altitude level, slopes, and vegetation cover for each point analyzed, using the geoprocessing tool "Intersection ...". This data made it possible to unify the information of these thematic layers in a single table, which lists the main geographical characteristics of the place where each event was analyzed in this research.

As a result, a GIS information layer was obtained containing the data of all the identified events, vegetation cover, level of altitude, range of slopes, type of geodynamic process, hydrographic basin, and occurrence date. With this information, a dynamic table and statistical graphics were generated to establish relationships between the variables, the discussion, and the postulation of conclusions.

\subsection{Weather data processing}

In order to analyze the meteorological conditions of the study area, historical data of precipitation and temperature were extracted from the Senamhi web portal and data was requested from the institution to complete the period 1963-2021 of five meteorological stations (EM) located in Huaraz province (Cajamarquilla, Pira, Chacchan, Pariacoto and Anta) and two in Recuay province (Recuay, Milpo). The meteorological data was consolidated in a matrix for each station, generating dynamic tables to determine annual rainfall and the average monthly rainfall represented in statistical graphics.

\subsection{Seismological activity analysis}

The technique of maximum epicentral distances of occurrence of instabilities was considered a function of the event's magnitude to determine the relationship between external geodynamic events and seismic activity in the study area (Keefer, 1984). The records of the Geophysical Institute of Peru - IGP's seismic database of the historical period (1471 - 1959) and the instrumental period (1960 - 2021) were obtained and consigned in the Des/nventar database corresponding to the period $1970-2013$.

\section{Results}

According to the typification of the 100 recorded events, it was determined that 49 are floods, within which are mud outflows (1), detrital floods (12), and other debris flows (36) such as the so-called huaycos; 33 records correspond to gravitational mass movements, which include landslides (25), rockslides (7) and soil creep (1); 5 come to be snow avalanches, and 13 are waterloggings.

By superimposing of the layers: event location, levels of altitude, slopes and river basins, the following results were obtained and are shown in Table 1:

\begin{tabular}{|c|c|c|c|c|c|c|c|c|c|c|c|c|c|c|c|c|}
\hline \multirow[t]{2}{*}{ Event type } & \multicolumn{5}{|c|}{ Level of altitude } & \multicolumn{7}{|c|}{ Slope } & \multicolumn{3}{|l|}{ Basin } & \multirow[t]{2}{*}{ Tc } \\
\hline & $\begin{array}{l}\text { Maritime } \\
\text { Yunga }\end{array}$ & Quechua & Suni & Puna & Cordillera & $\begin{array}{l}0- \\
4 \%\end{array}$ & $\begin{array}{l}4- \\
8 \%\end{array}$ & $\begin{array}{l}8- \\
15 \%\end{array}$ & $\begin{array}{l}15- \\
25 \%\end{array}$ & $\begin{array}{l}25- \\
50 \%\end{array}$ & $\begin{array}{l}50- \\
75 \%\end{array}$ & $75 \%$ & Culebras & Casma & Santa & \\
\hline $\begin{array}{l}\text { Snow } \\
\text { avalanche }\end{array}$ & & & & 1 & 4 & & & & 1 & 1 & 1 & 2 & & & 5 & 5 \\
\hline Waterlogging & & 13 & & & & 5 & 3 & 3 & & 2 & & & & & 13 & 13 \\
\hline Floods & 7 & 27 & 7 & 5 & 3 & 1 & 3 & 14 & 12 & 15 & 1 & 3 & 1 & 16 & 32 & $4 \mathrm{C}$ \\
\hline $\begin{array}{l}\text { Gravitational } \\
\text { motion in } \\
\text { mass }\end{array}$ & 4 & 20 & 7 & 2 & & 4 & & 5 & 4 & 15 & 4 & 1 & 1 & 6 & 26 & 33 \\
\hline Total & 100 & & & & & 100 & & & & & & & 100 & & & $1 \mathrm{C}$ \\
\hline
\end{tabular}

The Casma river basin is the $38 \%$ of the study area and contains $40 \%$ of the populated centers, registering $22 \%$ of the events in the province, where the levels of altitude of Maritime Yunga and Quechua represent $49 \%$ of the basin.

The Culebras river basin represents $12 \%$ of the province and contains $13 \%$ of the populated centers, registering only $2 \%$ of the events. The levels of altitude of Maritime Yunga and Quechua predominate, constituting $74 \%$ of the basin.

Finally, the Rio Seco Inter-basin constitutes $3 \%$ of the province and has the $0.2 \%$ of the populated centers; it does not register events in its area. It is located on the western slope of the Cordillera Negra and is distributed at the altitude levels of Maritime Yunga and Quechua.

\subsection{Physiography}

It is observed that almost three-quarters of the events (72) occurred in places with slopes between $8 \%$ and $50 \%$ (from strongly inclined to steep), and we found 16 events registered in places with a slope less than $8 \%$ (from flat to moderately sloping). There is a lower occurrence of events in those areas with very steep and extremely steep slopes (greater than $50 \%$ ), registering 12 events in total.

Concerning flood, there is a higher concentration ( $84 \%)$ on surfaces with a strongly inclined to the steep slope (8\% -50\%). Likewise, a similar occurrence (73\%) of gravitational mass movements in the same range of slope is evidenced, highlighting that it presents an incidence of $46 \%$ on steep surfaces ( $25 \%-50 \%$ ).

Indistinctly, waterlogging happens more frequently in areas with slopes less than $8 \%$, representing $62 \%$ of this type of event. In contrast, most snow avalanches (60\%) happen on steep and extremely steep slopes (more than $50 \%$ ). Likewise, snow avalanches do not happen in areas with less than $15 \%$ slopes.

\subsection{Events per month}


The highest concentration of events (close to $78 \%$ ) is related to more heavy rains between December and March.

The registered events have increased from December, registering 11 events with a higher flood occurrence (7). It increases to 12 events for January, half being mass gravitational movements. The figure rises to 16 events in February, predominantly floods (10). For March, there are a total of 31 occurrences, with a significant increase of $94 \%$ compared to December, being the month with the highest number of events (13 mass gravitational movements, 12 floods and 6 waterloggings).

However, for greater precision of the information, the study area is divided into two sectors based on the duration of the rainy season. In the case of the western slope of the Cordillera Negra, its meteorological stations show that more than $76 \%$ of the annual precipitation (CMS Pariacoto $81 \%$, CMS Chacchan $82 \%$, CMS Pira $77 \%$ ) is concentrated in only 4 months (December to March). While, in the case of the Santa River basin stations, it is observed that the wet season extends from October to April, the sum of which exceeds $78 \%$ of the annual precipitation (AMS Recuay $91 \%$, CMS Milpo 79\%).

Unlike other events, snow avalanches have a higher occurrence (80\%) in the dry season (May to August).

\subsection{Events per year}

The years with the highest occurrence of events, with 6 or more records each, were 1994 and 1998. Likewise, the years recorded between 3 and 5 occurrences were: 1970, 1972, 1980, 1981, 1991, 1993, 1997, 2001 and 2019. Consequently, those not mentioned years had less than 3 events or did not record any.

\subsection{Earthquakes}

Sixteen earthquakes, with 7 and 6 degrees and a range up to $200 \mathrm{~km}$ in the study area, were identified. When analyzing the earthquakes of greater magnitude, 6 earthquakes with a magnitude greater than $7^{\circ}$ were identified. In contrast, 244 earthquakes were counted for magnitudes between 4 and 6 up to a distance of $80 \mathrm{~km}$.

In general, a total of 7,849 earthquakes were recorded within an area of 500,000 square kilometres, or a radius of 398.94 kilometres, surrounding the Huaraz province, whose intensities fluctuate between $3.2^{\circ}$ and $8^{\circ}$ on the Richter scale. When comparing dates of occurrence between earthquakes and external geodynamic disasters, a total of 35 coincidences were identified. The comparison of the spatial geolocation of the earthquakes with the events studied shows that all the events occurred outside the area prone to instability due to earthquakes based on their magnitude.

\section{Discussion}

\subsection{Events per level of altitude}

The Quechua region, which represents $21 \%$ of the province's territory, registers the highest number of events (60), being $45 \%$ alluvial and $33 \%$ gravitational mass movements, caused by its rugged physiography and humid climate, being confirmed by Dávila (1994) when stating that from this region the precipitations are more intense, producing more severe effects of erosion in gullies and huaycos. Likewise, it is the only level of altitude that presents the occurrence of waterlogging (13) due to the existence of alluvial terraces and the broad valley of the Santa River (Gobierno Regional de Áncash, 2014).

Due to their highly rugged reliefs, the Maritime Yunga and Suni regions present floods and mass gravitational movements. According to Vergara et al. (2011), the factor preventing waterlogging in these altitude levels is the slope greater than $25 \%$, comprising $78.2 \%$ of the yungas and $68 \%$ in the Suni region. Only $0.4 \%$ is a flat or slightly sloping surface in the yungas and $1.1 \%$ in the Suni region (Gobierno Regional de Áncash, 2014).

The Puna and Cordillera regions have a low number of events (8 and 7 respectively), despite the strongly rugged physiography of the Cordillera, the presence of scattered grassy vegetation in the Puna, or the lack of vegetation cover on its summits that controls the erosive processes. It is due to the predominance of exposed rock surfaces (Cordillera) and shallow surface soils (Puna), implying a lower availability of erodible material. Likewise, as they are sparsely inhabited, the impact on populations, economic activities, or infrastructure is less, and in these cases, there may be an under-registration. Finally, it is specified that the occurrence of snow avalanches is restricted to these two levels of altitude, where the glaciers that originate them are located, and the periglacial zones that can be affected by them.

The Puna region is the largest (36\%) and presents the highest rainfall in the area (more than 1,000 $\mathrm{mm}$ per year); however, it registers few events ( $8 \%$ ), showing a low correlation (R2 $=0.0098)$ between the extension of the level of altitude, or its average annual rainfall, with the number of natural disasters.

In this sense, it is hypothesized that the Maritime Yunga, Suni and Cordillera regions, as they present steeper slopes, accumulate less sediment and regolith; consequently, they will be less affected by large mass movements. On the contrary, the Quechua Region, having a sub-humid to a humid climate, mild temperatures, favourable for the development of more vigorous plant covers (scrub, forests, dense grasslands), retains more sediments and regolith, in addition to presenting a more intense chemical weathering, it has better conditions for the formation of soils about the other levels of altitude present in the province.

Finally, it is necessary to specify that the vegetation cover of the Quechua region does not provide adequate protection to the soil (due to the low presence of forests and intense anthropic use), which leads to accelerated erosive processes.

\subsection{Events by basins}

Most of the events (76\%) occurred in the Santa River basin, representing 47\% of Huaraz province and containing $47 \%$ of all populated centers. Suni and Puna's predominant regions, accounting for $67 \%$ of its surface. Its meteorological stations register higher annual precipitation than the stations in the Casma River basin because they are located on the eastern slope of the Cordillera Negra with less influence from the cold Humboldt current.

Page $7 / 13$ 
It presents a direct relationship between the extension of the basin and the number of events $\left(R^{2}=0.7545\right)$. It also has a relationship between the number of populated centers and the number of events $\left(R^{2}=0.7038\right)$.

\subsection{Seasonal distribution of events occurrence}

A strong correlation is observed in Figure 2 between the annual distribution of precipitation and the occurrence of mass movements events $\left(\mathrm{R}^{2}=0.726\right)$. This relationship is similar to the results of other investigations such as Vilímek et al. (2013) and Hijar et al. (2016), who conclude that there is a cause-effect between hydrometeorological events and external geodynamic disasters.

In the present case, $77 \%$ of events happened during the months with more intense rainfall (December - March), a period in which $72 \%$ of the flood, $89 \%$ of mass movements and $100 \%$ of waterlogging are recorded. Mergili et al. (2015) stated that this is due to prolonged rains saturating different soil strata, generating instability in some areas. It should be noted that $48 \%$ of the total flood occurs in February and March since it would be caused by the surface runoff of the stream water, which is generated by intense rainfalls, even if this is of a short duration (Mergili et al., 2015).

In contrast, mass gravitational movements show a concentration of $48 \%$ only in March (end of the rainy season). According to Vit Vilímek et al. (2013), these phenomena are associated with the infiltration of water into deeper strata, requiring an abundant rainfall contribution of long duration or cumulatively, which reaches the maximum saturation levels at the end of the wet period.

$75 \%$ of the waterlogging is concentrated in February and March, caused by the overflow of rivers that exceed their carrying capacity after the fall of the most intense rainfall (Tinoco Meyhuay, 2019), which generally happen in these months. Likewise, $50 \%$ of all waterlogging is concentrated in March, which coincides with the maximum water saturation of the soil.

However, the low number of identified events makes it unrepresentative, and there may be significant underreporting. On the contrary, $80 \%$ of the snow avalanches were registered in the dry season (May - November), where there is a minimum contribution of rainfall and a long time of exposure of the glacier to the solar radiation (due to less cloud cover). These events happen in places far from populations and infrastructure that may be affected, being observed only by people who climb the mountains only in the dry season, but not in the rainy season because it is considered high risk.

\subsection{ENSO and its influence on the occurrence of events}

It was determined that there is a relationship between ENSO and the occurrence of events in the years: 1994 (moderate ENSO) and 1997-1998 (extreme ENSO), whose cases would coincide with the conclusions of the investigations carried out by Bouma et al. (1997), Chen et al. (2019), Concha et al. (2017), Dilley \& Heyman (1995) and Vilímek et al. (2013), who assure that the presence of ENSO on the Peruvian coast generates copious rainfall that triggers floods, landslides and waterlogging, on the western slope of the Andes.

The year with the highest number of disasters in Huaraz province was 1994, with 8 events. However, when analyzing the interannual periods, it was determined that the period from September 1997 to April 1998 (extreme ENSO) registered a total of 11 events, constituting the period with the highest incidence of this type of natural disaster.

However, the manifestation of an extreme ENSO does not necessarily generate events in the area, as in the extreme ENSO of $1982-83$ and the coastal ENSO of 2017. These events registered 2 events for each period, with no registration for the ENSOs of 1891 and 1925-26. This situation is because most of the province's territory is in the Quechua, Suni and Puna regions, less affected by ENSO. Likewise, $47 \%$ of the study area is located in the Santa river basin, whose air masses are less influenced by the conditions of the Peruvian sea due to the Cordillera Negra that constitutes a biogeographic barrier.

\subsection{The slope as a determining factor in the occurrence of events}

The areas with very steep and highly steep slopes constitute $36.4 \%$ of the study area and record only $12 \%$ of the events. Most have superficial soils covered by shrub and herbaceous vegetation ( $73 \%$ of their extension) or surfaces devoid of soil such as glaciers or exposed rock (22\% of their extension). In these sectors, steep slopes and rapid runoff prevent water accumulation and infiltration, reducing the likelihood of flooding and mass gravitational movements.

Places strongly inclined to steep slopes ( $60.5 \%$ of the province) have registered $72 \%$ of all events. This result is attributed to the undulating relief, which can conserve a more significant amount of particulate material, allowing more infiltration due to the presence of deep soils, maintaining a significant altitude variation (potential energy) and torrential runoff that, having poor plant protection (grasses and bushes), is susceptible to mass gravitational movements and flood.

The flat to moderately sloping areas ( $3 \%$ of the study area) concentrate $16 \%$ of the records, of which half are waterloggings, in most cases happening in areas with slopes less than $4 \%$, typified as susceptible to this phenomenon (Vergara et al., 2011). For this reason, it can be deduced that waterlogging can only happen in alluvial terraces of the Santa River, Uquian stream, Rurec stream, and the Quilcay stream cone because they present a slow runoff, where infiltration is prolonged, leading to waterlogging when the soil is saturated. It should be noted that $81 \%$ of the disasters happened in places with low slopes in Huaraz city, where a quarter corresponds to rockslides from the outcrop called "El Balcón de Judas", which shows the high risk to which its inhabitants are exposed. The remaining events correspond to floods that happened mainly in periglacial lagoons.

Finally, it was found that $60 \%$ of the snow avalanches happened in places with very steep to extremely steep slopes, predominant in the Cordillera Blanca.

\subsection{Floods as the most recurring type of event}

In Huaraz province, the most frequent events are floods that account for $49 \%$ of all records. During the $1997-1998$ ENSO, floods constituted $73 \%$ of all disasters. They occur mainly in the Quechua region and in the Santa river basin, where the areas with slopes between $8 \%$ and $50 \%$ are more susceptible, with a 
significant incidence in February and March.

According to Véliz (1974) and Carey et al. (2012), these disasters could increase due to Climate Change, which accelerates the glacial retreat in the Cordillera Blanca, destabilizing the moraines that dam lakes, changes the precipitation patterns and increases the frequency and intensity of ENSOs. These factors would cause a greater availability of water in the territory, increasing runoff flows and erosive processes, which associated with the rugged physiography of Huaraz province will produce a more significant number of floods. The most affected area will be the Quechua level because of the higher population density and poor vegetation cover due to intense anthropic pressure.

\section{Conclusion}

The Quechua region is the altitudinal level most affected by events of mass movements as it has a higher population density and better climatic and topographic conditions.

The hydrographic basins located on the western slope of the Cordillera Negra register a lower number of events due to their arid climate- influenced by the cold Humboldt Current - and small areas compared to the Santa River basin, which accounts for most natural disasters.

There is a relationship between the occurrence of flood, mass movements and waterlogging with the monthly distribution of rainfall, which occurs mainly in the wet period of the year.

Only some ENSOs can generate external geodynamic disasters in Huaraz province since each process presents different characteristics regarding its place of occurrence, intensity, places of impact, and duration.

Areas strongly inclined to steep slopes (8\%-50\%) are more prone to external geodynamic disasters, except for waterlogging and snow avalanches. Waterlogging occurs in flat to slightly sloping areas $(<4 \%)$ that are highly populated locations, and snow avalanches happen on glaciers with very steep to highly steep slopes $(>50 \%)$.

Floods are the most recurrent process occurring mainly in the Quechua region, in the Santa River basin, in areas with slopes between $8 \%$ and $50 \%$, and between February and March.

\section{Declarations \\ Conflicts of interest}

The authors have no conflicts of interest to declare.

\section{Acknowledgments}

This research has been supported by the Faculty of Engineering of the Universidad Privada del Norte. Thanks are extended to the National Meteorology and Hydrology Service for providing meteorological data for the study area.

\section{References}

1. Alvarez, M. I. (2020). MODELAMIENTO DEL HIDROGRAMA DE RUPTURA MEDIANTE CARACTERÍSTICAS HIDROMÉTRICAS Y PROPIEDADES MECÁNICAS DEL SUELO DEL DIQUE NATURAL DE LA LAGUNA PALCACOCHA, HUARAZ. 2019 [UNIVERSIDAD NACIONAL SANTIAGO ANTÚNEZ DE MAYOLO]. In Repositorio Institucional. http://repositorio.unasam.edu.pe/handle/UNASAM/4337

2. Balzano, B., Tarantino, A., \& Ridley, A. (2019). Preliminary analysis on the impacts of the rhizosphere on occurrence of rainfall-induced shallow landslides. Landslides, 16(10), 1885-1901. https://doi.org/10.1007/s10346-019-01197-5

3. Bonnot, D. (1984). Neotectonique et tectonique active de la Cordillère Blanche et du Callejon de Huaylas (Andes nord-péruviennes). https://tel.archivesouvertes.fr/tel-00716438

4. Bouma, M., Kovats, R., Goubet, S., Cox, J. S. H., \& Haines, A. (1997). Global assessment of El Niño's disaster burden. The Lancet, 350(9089), $1435-1438$. https://doi.org/10.1016/S0140-6736(97)04509-1

5. Britto, B. (2017). Actualización de las Ecorregiones Terrestres de Perú propuestas en el Libro Rojo de Plantas Endémicas del Perú. Gayana. Botánica, 74(1), 15-29. https://doi.org/10.4067/S0717-66432017005000318

6. Carey, M., Huggel, C., Bury, J., Portocarrero, C., \& Haeberli, W. (2012). An integrated socio-environmental framework for glacier hazard management and climate change adaptation: lessons from Lake 513, Cordillera Blanca, Peru. Climatic Change, 112(3-4), 733-767. https://doi.org/10.1007/s10584-0110249-8

7. Casamitjana, M., \& Carl, R. (2019). Movimientos en masa (Fondo Edit). https://elibro-net.eu1.proxy.openathens.net/es/ereader/upnorte/130285

8. Castaños, H., \& Lomnitz, C. (2012). The 1970 Peru Earthquake (pp. 25-30). https://doi.org/10.1007/978-94-007-2810-3_4

9. Casteller, A., Villalba, R., Mayer, A., \& Stöckli, V. (2009). Reconstrucción espacial y temporal de la ocurrencia de avalanchas de nieve en los Andes patagónicos utilizando técnicas dendrocronológicas. Revista Chilena de Historia Natural, 82(2), 245-264. https://doi.org/10.4067/S0716078X2009000200007 
10. Chacón, N., Jacay, J., \& Moreno, I. (2005). Procesos geodinámicos en el área río Quillcay, Huaraz - Ancash. Revista Del Instituto de Investigación de La Facultad de Ingeniería Geológica, Minera, Metalurgica y Geográfica, 8(16), 22-28.

https://revistasinvestigacion.unmsm.edu.pe/index.php/iigeo/article/view/703/556

11. Chen, N., Thual, S., \& Hu, S. (2019). El Niño and the Southern Oscillation: Observation. In Reference Module in Earth Systems and Environmental Sciences (Issue December 2018, pp. 1-7). Elsevier. https://doi.org/10.1016/B978-0-12-409548-9.11766-X

12. Concha, R., Valdivia, W., Vásquez, P., \& Benites, A. (2017). Informe Técnico N A 6763. Evaluación geológica de las zonas afectadas por El Niño Costero 2017 en la región Ancash. https://repositorio.ingemmet.gob.pe/handle/20.500.12544/814

13. Cruden, D. M. (1991). A simple definition of a landslide. Bulletin of the International Association of Engineering Geology, 43(1), 27-29. https://doi.org/10.1007/BF02590167

14. Dávila, S. (1994). ESTUDIO GEODINAMICO DE LA CUENCA DEL RIO CASMA- SECHIN. https://repositorio.ingemmet.gob.pe/handle/20.500.12544/237

15. Dilley, M., \& Heyman, B. N. (1995). ENSO and Disaster: Droughts, Floods and El Niño/Southern Oscillation Warm Events. Disasters, 19(3), $181-193$. https://doi.org/10.1111/j.1467-7717.1995.tb00338.x

16. Doyle, F. J. (1978). Digital Terrain Models: An Overview. Photogrammetric Engineering and Remote Sensing, 44(12), 1481-1485. https://www.asprs.org/wp-content/uploads/pers/1978journal/dec/1978_dec_1481-1485.pdf

17. Emmer, A. (2017). Geomorphologically effective floods from moraine-dammed lakes in the Cordillera Blanca, Peru. Quaternary Science Reviews, 177, 220-234. https://doi.org/10.1016/j.quascirev.2017.10.028

18. Fan, R. L., Zhang, L. M., Wang, H. J., \& Fan, X. M. (2018). Evolution of debris flow activities in Gaojiagou Ravine during 2008-2016 after the Wenchuan earthquake. Engineering Geology, 235, 1-10. https://doi.org/10.1016/j.enggeo.2018.01.017

19. Ferro, V. (2009). La evaluación del riesgo de desastre en la planificación del desarrollo de la ciudad de Huaraz, Áncash. In ANÁLISIS DEL RIESGO EN PROCESOS DE DESARROLLO E INVERSIÓN (pp. 145-189). http://bvpad.indeci.gob.pe/doc/pdf/esp/doc1298/doc1298-contenido.pdf\#page=149

20. Frey, H., Huggel, C., Chisolm, R. E., Baer, P., McArdell, B., Cochachin, A., \& Portocarrero, C. (2018). Multi-Source Glacial Lake Outburst Flood Hazard Assessment and Mapping for Huaraz, Cordillera Blanca, Peru. Frontiers in Earth Science, 6(November), 1-16. https://doi.org/10.3389/feart.2018.00210

21. Gobierno Regional de Áncash. (2014). Estudio de diagnóstico y zonificación con fines de demarcación territorial de la provincia de Huaraz. http://sdot.pcm.gob.pe/wp-content/uploads/2016/06/EDZ-Huaraz.pdf

22. Guevara, M. del R. (2017). GEOLOGÍA. GEODINÁMICA EXTERNA. In RUA MX. https://www.rua.unam.mx/portal/recursos/ficha/84567/geologiageodinamica-externa

23. Hegglin, E., \& Huggel, C. (2008). An Integrated Assessment of Vulnerability to Glacial Hazards. Mountain Research and Development, 28(3/4), 299-309. https://doi.org/10.1659/mrd.0976

24. Hijar, G., Bonilla, C., Munayco, C. V., Gutierrez, E. L., \& Ramos, W. (2016). Fenómeno El Niño y desastres naturales: intervenciones en salud pública para la preparación y respuesta. Revista Peruana de Medicina Experimental y Salud Pública, 33(2), 300-310. https://doi.org/10.17843/rpmesp.2016.332.2205

25. Huang, R., \& Li, W. (2014). Post-earthquake landsliding and long-term impacts in the Wenchuan earthquake area, China. Engineering Geology, 182(PB), 111-120. https://doi.org/10.1016/j.enggeo.2014.07.008

26. Hungr, O., Leroueil, S., \& Picarelli, L. (2014). The Varnes classification of landslide types, an update. Landslides, 11(2), 167-194. https://doi.org/10.1007/s10346-013-0436-y

27. Indeci. (2003a). MAPA DE PELIGROS DE LA CIUDAD DE HUARAZ. http://bvpad.indeci.gob.pe/doc/estudios_CS/Region_Ancash/ancash/huaraz_mp.pdf

28. Indeci. (2003b). Plan de Prevención ante desastres: Uso del suelo y medidas de mitigación ciudad de Huaraz. http://bvpad.indeci.gob.pe/doc/estudios_CS/Region_Ancash/ancash/huaraz.pdf

29. INEI. (2018). ÁNCASH - RESULTADOS DEFINITIVOS DE CENSOS NACIONALES 2017. https://www.inei.gob.pe/media/MenuRecursivo/publicaciones_digitales/Est/Lib1552/02TOMO_01.pdf

30. Ingemmet. (1989). Estudio Geodinámico de la Cuenca del Río Santa. https://repositorio.ingemmet.gob.pe/handle/20.500.12544/313

31. Iverson, R. M. (2000). Landslide triggering by rain infiltration. Water Resources Research, 36(7), 1897-1910. https://doi.org/10.1029/2000WR900090

32. Kargel, J. S., Leonard, G. J., Shugar, D. H., Haritashya, U. K., Bevington, A., Fielding, E. J., Fujita, K., Geertsema, M., Miles, E. S., Steiner, J., Anderson, E., Bajracharya, S., Bawden, G. W., Breashears, D. F., Byers, A., Collins, B., Dhital, M. R., Donnellan, A., Evans, T. L., ... Young, N. (2016). Geomorphic and geologic controls of geohazards induced by Nepals 2015 Gorkha earthquake. Science, 351(6269), 1-18. https://doi.org/10.1126/science.aac8353

33. Keefer, D. (1984). Landslides caused by earthquakes. GSA Bulletin, 95(4), 406-421. https://doi.org/https://doi.org/10.1130/00167606(1984)95\&amp;amp;It;406:LCBE\&amp;amp;gt;2.0.CO;2

34. Khattak, G. A., Owen, L. A., Kamp, U., \& Harp, E. L. (2010). Evolution of earthquake-triggered landslides in the Kashmir Himalaya, northern Pakistan. Geomorphology, 115(1-2), 102-108. https://doi.org/10.1016/j.geomorph.2009.09.035

35. Laimer, H. J. (2017). Anthropogenically induced landslides - A challenge for railway infrastructure in mountainous regions. Engineering Geology, 222, 92-101. https://doi.org/10.1016/j.enggeo.2017.03.015

36. Lario, J., \& Bardají, T. (2017). Introducción a los riesgos geológicos (Editorial UNED (ed.)). Universidad Nacional de Educación a Distancia. https://books.google.es/books?id=_WgYDgAAQBAJ\&printsec=frontcover\&hl=es\&source=gbs_ge_summary_r\&cad=0\#v=onepage\&q\&f=false

37. Lin, W.-T., Chou, W.-C., Lin, C.-Y., Huang, P.-H., \& Tsai, J.-S. (2007). Study of landslides caused by the 1999 Chi-Chi earthquake, Taiwan, with multitemporal SPOT images. Canadian Journal of Remote Sensing, 33(4), 289-302. https://doi.org/10.5589/m07-036 
38. Liu, Z., Dai, L., Li, S., Li, Z.-H., Ding, X., Bukhari, S. W. H., \& Somerville, I. (2020). Earth's surface responses during geodynamic evolution: Numerical insight from the southern East China Sea Continental Shelf Basin, West Pacific. Gondwana Research. https://doi.org/10.1016/j.gr.2020.12.011

39. Martha, T. R., Roy, P., Mazumdar, R., Govindharaj, K. B., \& Kumar, K. V. (2017). Spatial characteristics of landslides triggered by the 2015 Mw 7.8 (Gorkha) and Mw 7.3 (Dolakha) earthquakes in Nepal. Landslides, 14(2), 697-704. https://doi.org/10.1007/s10346-016-0763-x

40. Mas-pla, J., \& Bach, J. (2008). Los Riesgos Geológicos en el Sistema de Cuenca: In P. Andrés \& R. Rodríguez (Eds.), Evaluacion y Prevencion de Riesgos Ambientales en Centroamérica (pp. 53-79). http://www.creaf.uab.es/propies/pilar/LibroRiesgos/03_Cap\%EDtulo2.pdf

41. Medina, J. (1991). FENÓMENOS GEODINÁMICOS. Estudio y medidas de tratamiento. (R. Carrera (ed.); Tecnología). https://books.google.es/books?

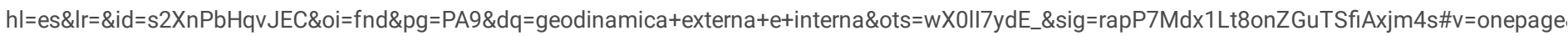
externa e interna\&f=false

42. Medina, L., \& Gonzales, J. (2018). Peligros geohidrológicos que ocasionaron daños en la ciudad de Trujillo durante " El Niño Costero ." Taller Internacional Fortalecimiento de Capacidades Para Mitigar Los Impactos de Huaicos En Perú, Lima y Arequipa, Perú, 15-19 Octubre 2018: Libro de Resúmenes, 31-33. https://repositorio.ingemmet.gob.pe/bitstream/20.500.12544/2588/1/Medina-Peligros_geohidrológicos_Trujillo.pdf

43. Meléndez de la Cruz, J. F. (2018). Geomorfología y peligros de origen natural en laderas aledañas a la localidad de Huallanca, provincia de Huaylas, departamento de Áncash. Investigaciones Sociales, 21(38), 87-96. https://doi.org/10.15381/is.v21i38.14216

44. Menacho Agama, J. (2018). Estrategias de fortalecimiento de capacidades para adaptación al cambio climático en comunidades de alta montaña de la subcuenca del río Quillcay en Áncash, Perú. APORTE SANTIAGUINO, 11(1), 95. https://doi.org/10.32911/as.2018.v11.n1.459

45. Mergili, M., Marchant Santiago, C. I., \& Moreiras, S. M. (2015). Causas, características e impacto de los procesos de remoción en masa, en áreas contrastantes de la región Andina. Cuadernos de Geografía: Revista Colombiana de Geografía, 24(2), 113-131.

https://doi.org/10.15446/rcdg.v24n2.50211

46. Oliver-Smith, A. (2014). Climate Change Adaptation and Disaster Risk Reduction in Highland Peru. In B. C. Glavovic \& G. P. Smith (Eds.), Adapting to Climate Change (pp. 77-100). Springer Netherlands. https://doi.org/10.1007/978-94-017-8631-7_4

47. Pulgar Vidal, J. (2014). Las ocho regiones naturales del Perú. Terra Brasilis, 3. https://doi.org/10.4000/terrabrasilis.1027

48. Rahman, A., Khan, A. N., \& Collins, A. E. (2014). Analysis of landslide causes and associated damages in the Kashmir Himalayas of Pakistan. Natural Hazards, 71(1), 803-821. https://doi.org/10.1007/s11069-013-0918-1

49. Rahman, A., Khan, A. N., Collins, A. E., \& Qazi, F. (2011). Causes and extent of environmental impacts of landslide hazard in the Himalayan region: a case study of Murree, Pakistan. Natural Hazards, 57(2), 413-434. https://doi.org/10.1007/s11069-010-9621-7

50. Ribeiro de Figueiredo, A. (2017). A sociocriosfera nos Andes Centrais: percepções, adaptações e impactos dos desastres glaciais no Callejón de Huaylas, Peru [UNIVERSIDADE FEDERAL DO RIO GRANDE DO SUL]. https://www.lume.ufrgs.br/handle/10183/156775

51. Sandoval, A. (2019). EVALUACIÓN DEL RIESGO POR GEODINÁMICA EXTERNA Y PROPUESTA DE MEDIDAS ESTRUCTURALES Y NO ESTRUCTURALES EN LA MICROCUENCA DE PAMPACHECTA, 2017 [Universidad Nacional Federico Villarreal]. http://repositorio.unfv.edu.pe/handle/UNFV/3669

52. Sanz-Ramos, M., Bladé, E., Torralba, A., \& Oller, P. (2020). Las ecuaciones de Saint Venant para la modelización de avalanchas de nieve densa. Ingeniería Del Agua, 24(1), 65-79. https://doi.org/10.4995/ia.2020.12302

53. Schweizer, J., Jamieson, J. B., \& Schneebeli, M. (2003). Snow avalanche formation. Reviews of Geophysics, 41(4), 1016. https://doi.org/10.1029/2002RG000123

54. Senamhi. (2014). El fenómeno El Niño en el Perú. https://issuu.com/senamhi_peru/docs/el_nino

55. Serey, A., Piñero-Feliciangeli, L., Sepúlveda, S. A., Poblete, F., Petley, D. N., \& Murphy, W. (2019). Landslides induced by the 2010 Chile megathrust earthquake: a comprehensive inventory and correlations with geological and seismic factors. Landslides, 16(6), 1153-1165.

https://doi.org/10.1007/s10346-019-01150-6

56. Silva Lindo, M., Reyes Roque, R., Rodríguez Anaya, R., \& Jara Palmadera, G. (2017). Análisis preliminar de la vulnerabilidad física ante desbordes en la zona de influencia de la quebrada río Seco de la ciudad de Huaraz en el año 2015. APORTE SANTIAGUINO, 9(2), 193-204.

https://doi.org/10.32911/as.2016.v9.n2.194

57. Silva, M. A. (2018). PERCEPCIÓN SOCIAL DEL PELIGRO Y VULNERABILIDAD FÍSICA Y AMBIENTAL ANTE DESASTRES EN LA ZONA RIBEREÑA DEL RÍO SECO DE LA CIUDAD DE HUARAZ EN EL AÑO 2015[UNIVERSIDAD NACIONAL SANTIAGO ANTÚNEZ DE MAYOLO].

http://repositorio.unasam.edu.pe/bitstream/handle/UNASAM/2910/T033_31621028_D.pdf?sequence=1\&isAllowed=y

58. Strahler, A. N. (1989). Geografía Física, 3a Edición Omega, Barcelona, España. (p. 621).

59. Suarez, J. (1998). Deslizamientos y Estabilidad Taludes en Zonas Tropicales (Ingeniería de Suelos Ltda. (ed.)). Instituto de Investigaciones sobre Erosión y Deslizamientos. http://desastres.usac.edu.gt/documentos/docgt/pdf/spa/doc0101/doc0101.pdf

60. Tacconi Stefanelli, C., Vilímek, V., Emmer, A., \& Catani, F. (2018). Morphological analysis and features of the landslide dams in the Cordillera Blanca, Peru. Landslides, 15(3), 507-521. https://doi.org/10.1007/s10346-017-0888-6

61. Tarbuck, E. J., \& Lutgens, F. (2005). Ciencias de la Tierra UNA INTRODUCCIÓN A LA GEOLOGÍA FíSICA. In PEARSON PRENTICE HALL (Ed.), Pearson Educación S. A. (Vol. 8, Issue 1). (c) 2005 por PEARSON EDUCACIÓN S. A.

62. Tinoco Meyhuay, T. (2019). Modelamiento del riesgo de inundación por la ocurrencia de descargas máximas del rio Santa, sector Challhua, HuarazAncash. Aporte Santiaguino, 12(2), 214-227. https://doi.org/10.32911/as.2019.v12.n2.643

63. Valderrama Murillo, P. A., Araujo Huamán, G. E., Dueñas Bravo, S., Silva Espejo, R. C., \& Fídel Smoll, L. (2016). Inventario de movimientos en masas, peligros geológicos y simulación de aluviones en la Cordillera Blanca, Ancash - Perú. Congreso Peruano de Geología, 18, Lima., 5.

http://repositorio.ingemmet.gob.pe/handle/20.500.12544/2752\#.X_Ws-kdaaY.mendeley

Page $11 / 13$ 
64. Valderrama, P., Pari, W., Silva, C., \& Fídel, L. (2013). Evaluación Ingeniero - Geológico: Laguna Palcacocha y su Influencia en la ciudad de Huaraz Cordillera Blanca. Región Ancash. In Informe Técnico N A663. http://sigrid.cenepred.gob.pe/docs/PARA PUBLICAR/INGEMMET/Informe tecnico Laguna de Palcacocha, 2013.pdf\#: :text=En el departamento de Ancash,así el Callejón de Huaylas.

65. Valdez, A. (2015). SISTEMA DE MONITOREO Y ALERTA TEMPRANA DE ALUVIONES EN LA QUEBRADA HUAYCOLORO PARA EL INSTITUTO GEOFÍSICO DEL PERÚ Y SEDAPAL [UNIVERSIDAD NACIONAL DE INGENIERÍA]. http://cybertesis.uni.edu.pe/bitstream/uni/1130/1/lopez_gj.pdf

66. Varnes, D. (1978). Slope Movement Types and Processes. Special Report, 176, 11-33. http://onlinepubs.trb.org/Onlinepubs/sr/sr176/176-002.pdf

67. Véliz, J. (1974). INFORME GEOLOGICO GLACIOLOGICO SOBRE CONDICIONES DE SEGURIDAD DEL CONO ALUVIONICO DE HUARAZ. https://190.12.92.167/handle/20.500.12543/2710

68. Vergara, C., Ellis, E. A., Alarcón, C., \& Galván, U. (2011). La conceptualización de las inundaciones y la percepción del riesgo ambiental. Política y Cultura, 36, 45-69. http://www.scielo.org.mx/scielo.php?script=sci_arttext\&pid=S0188-77422011000200003

69. Vilímek, Vít, Emmer, A., Huggel, C., Schaub, Y., \& Würmli, S. (2014). Database of glacial lake outburst floods (GLOFs)-IPL project No. 179. Landslides, 11(1), 161-165. https://doi.org/10.1007/s10346-013-0448-7

70. Vilímek, Vit, Hanzlík, J., Sládek, I., Šandov, M., \& Santillán, N. (2013). The Share of Landslides in the Occurrence of Natural Hazards and the Significance of El Niño in the Cordillera Blanca and Cordillera Negra Mountains, Peru. In K. Sassa, B. Rouhban, S. Briceño, M. McSaveney, \& B. He (Eds.), Landslides: Global Risk Preparedness (pp. 133-148). Springer Berlin Heidelberg. https://doi.org/10.1007/978-3-642-22087-6_9

71. Zavala, B., Gómez, J. C., \& Herrera, B. (2010). DESLIZAMIENTO DEL CERRO RODEOPAMPA Y EMBALSE DEL RIO SOCOTA - REGION CAJAMARCA. https://repositorio.ingemmet.gob.pe/handle/20.500.12544/189

\section{Figures}

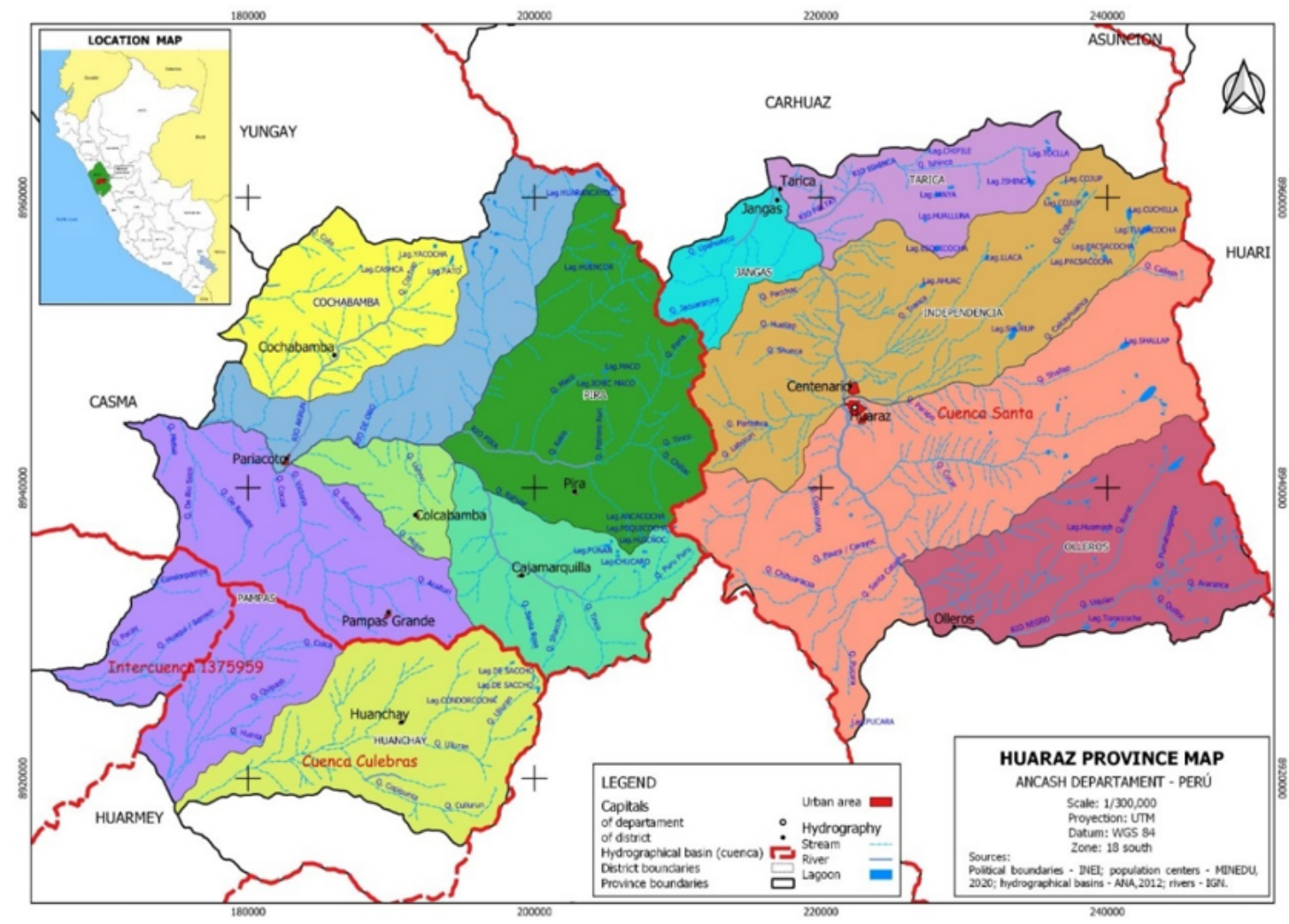

\section{Figure 1}

Map of Huaraz province - area of study 


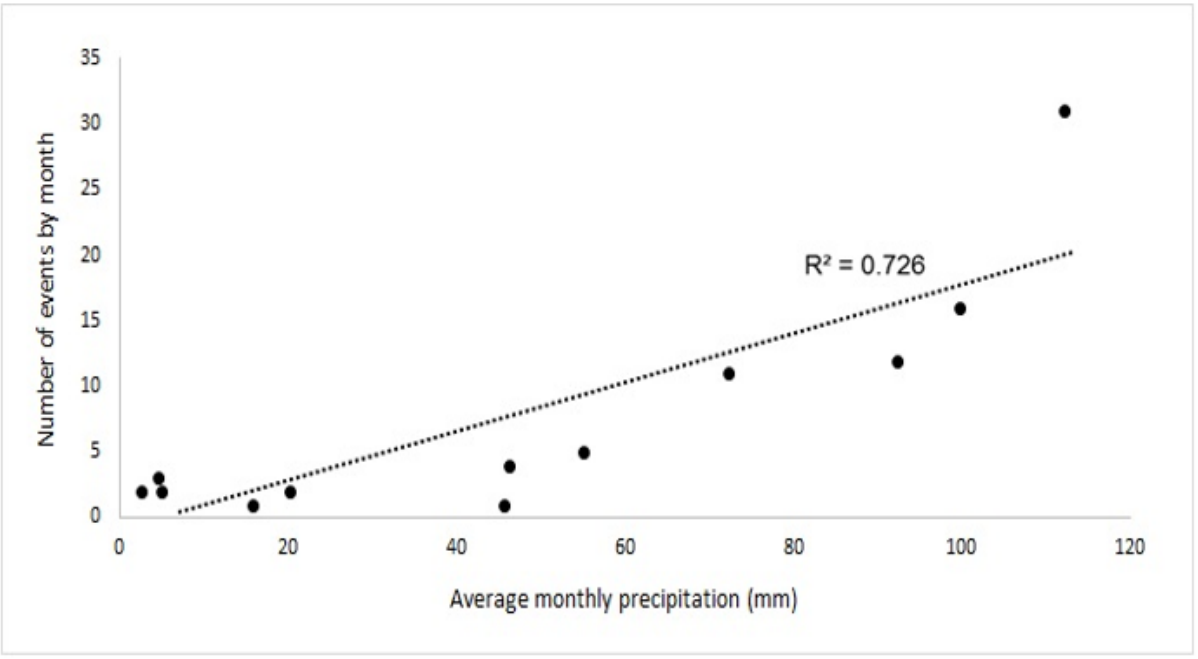

Figure 2

Correlation between the occurrence of events and average monthly precipitation 